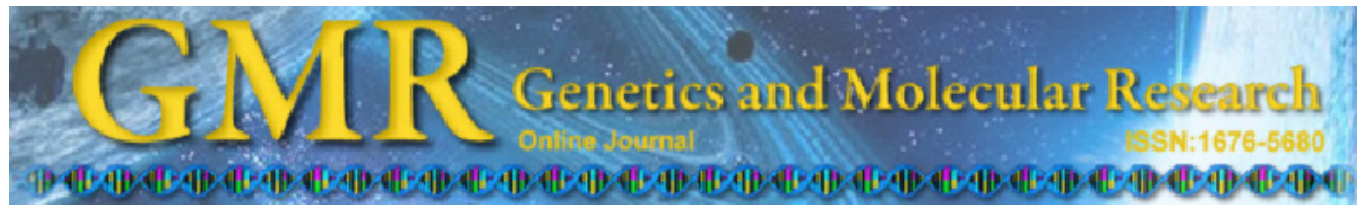

\title{
Expression profile of insulin-like growth factor system genes in muscle tissues during the postnatal development growth stage in ducks
}

\author{
C.-L. Song, ${ }^{1,2}$, H.-H. Liu ${ }^{1}$, J. Kou ${ }^{1}$, L. Lv ${ }^{1}$, L. Li ${ }^{1}$, W.-X. Wang ${ }^{1}$ and \\ J.-W. Wang ${ }^{1}$ \\ ${ }^{1}$ Institute of Animal Breeding and Genetics, Sichuan Agricultural University, \\ Ya'an, Sichuan Province, China \\ ${ }^{2}$ Ya'an Vocational College, Ya'an, Sichuan Province, China \\ Corresponding author: J.-W. Wang \\ E-mail: wjw2886166@163.com
}

Genet. Mol. Res. 12 (4): 4500-4514 (2013)

Received May 21, 2012

Accepted December 15, 2012

Published May 6, 2013

DOI http://dx.doi.org/10.4238/2013.May.6.3

\begin{abstract}
Insulin-like growth factors (IGFs) are regulators that modulate the proliferation and differentiation of muscle tissues. We quantified the messenger RNA (mRNA) expression of IGF-I, IGF-II, and type I and II IGF receptors (IGF-IR and IGF-IIR) in muscle tissues including the breast, leg, and myocardium during an early postnatal development growth stage (post-hatching weeks 1-8) in ducks. The results showed a significant age-related change in mRNA in these muscle tissues. In breast muscle, the developmental expression of IGF-I and IGF-II was highest during week 1 but decreased quickly and maintained a relatively lower level. Leg muscle had the highest mRNA expression of IGF-I and IGF-II genes at week 3. In myocardial tissues, the expression level of IGF-IR and IGF-IIR genes exhibited a "rise-decline" developmental trend. The expression patterns of IGF-I/ IGF-IR and IGF-II/IGF-IIR were different between weeks 4 and 6 . The same expression pattern was observed for IGF-I and IGF-IR; however, it was different from that observed for IGF-II and IGF-IIR. Our results showed a negative correlation between IGF-II mRNA expression and leg muscle weight at week $4(\mathrm{P}<0.05)$. A negative correlation was also found between IGF-II mRNA expression and breast muscle weight $(\mathrm{P}<$
\end{abstract}


0.01 ), and a positive correlation was found between IGF-IR expression and breast muscle weight. At week 6, a positive correlation was found between IGF-IR expression and breast muscle weight. However, at week 8 , a negative correlation was found between IGF-IR expression and breast muscle weight. The results showed that the expression of IGF mRNA in duck tissues exhibits a specific developmental trend and an age-related pattern, suggesting that the regulation mechanism of these 4 genes in proliferation and differentiation of muscle tissues differed.

Key words: Insulin-like growth factors; Muscle tissue; Expression pattern

\section{INTRODUCTION}

The insulin-like growth factor (IGF) system, consisting of 2 growth factors (IGF-I and IGF-II), 2 IGF receptors [IGF-IR and IGF-IIR/cation-independent mannose 6-phosphate receptor (M6PR)], and 7 IGF-binding proteins (IGFBP1-7), has been characterized as an important regulatory system for controlling tissue growth and development in vertebrates (Richards et al., 2005; Castigliego et al., 2010; Wu et al., 2011). IGF can regulate cellular proliferation and differentiation through the endocrine and auto/paracrine systems (Jones and Clemmons, 1995; Simmen et al., 1998; Liu and LeRoith, 1999; Xu et al., 2012). The expression of IGF system genes has been studied throughout development in many mammalian tissues including liver, muscle, bone, reproductive organs, and the central nervous system (Huybrechts et al., 1985; Allan et al., 2001; Dupont and Holzenberger, 2003; Brown et al., 2009; Harris and Westwood, 2012).

In mammals, IGF-I is thought to play an important role in mediating the effects of growth hormones on tissue growth during postnatal development, whereas IGF-II reportedly functions primarily during embryonic growth and development (Scanes et al., 1989; Duclos et al., 1999; Dupont and Holzenberger, 2003; Richards et al., 2005). IGF-IR, which exhibits tyrosine kinase activity, plays a key role throughout development in birds by regulating the growth and differentiation of a variety of tissues, including those of the central nervous system (Holzenberger et al., 1996, 2000). One report has highlighted the effects of development and nutritional status on the expression of IGF-I, IGF-II, IGF-IR, IGFBP2, and IGFBP5 genes in various avian tissues (McMurtry and Brocht, 1997; McMurtry, 1998; Allan et al., 2001). Unlike mammalian cells, chicken cells do not express a second IGF receptor type (type 2 IGF receptor) with a selective specificity for IGF-II (Duclos et al., 1991; Lu et al., 2009). Chicken muscle satellite cells, like cells in other chicken tissues, express a unique IGF receptor (type 1 IGF receptor, or IGF-IR) with similar high affinities for human IGF-I and IGF-II and a low affinity for insulin (Duclos et al., 1991; Lu et al., 2009). IGFs can also stimulate muscle differentiation by upregulating the transcription of myogenin (Florini et al., 1991; Tiffin et al., 2004).

However, less knowledge is available about the developmental characteristics of IGFs in animal muscle tissues, especially during the early postnatal growth stage. Nevertheless, the postnatal developmental stage is critical for muscle hypertrophy. The IGFs have been shown to regulate body and muscle growth in chickens (Pym et al., 1991; Frost and Lang, 2003; Heinemeier et al., 2012; Lunetta et al., 2012), but no comparisons of different muscle tissues have been published. The duck is an ideal animal model to research the expression characteristics of IGF system genes during the postnatal early growth stage because muscle hypertrophy 
and development in ducks is highly concentrated during the postnatal stage. Therefore, in this study we used a quantitative real-time polymerase chain reaction (qRT-PCR) technique to investigate and compare the expression patterns of IGF-I, IGF-II, IGF-IR, and IGF-IIR genes in breast muscle, leg muscle, and myocardial tissue during the postnatal early development growth stage in ducks to determine the essential roles of IGFs during this stage.

\section{MATERIAL AND METHODS}

\section{Animals}

We used Pekin ducks at different ages $(1,2,3,4,5,6,7$, and 8 weeks) provided by the farm for experimental poultry breeding at Sichuan Agricultural University. The animals were killed, and breast muscle, leg muscle, and myocardial tissues were collected and weighted. Tissue samples were snap-frozen in liquid nitrogen and then stored at $-80^{\circ} \mathrm{C}$ for total RNA extraction.

\section{RNA isolation and cDNA synthesis}

Total RNA was isolated from the breast muscle, leg muscle, and myocardial tissues of ducks using the TRIzol reagent (Invitrogen, USA) according to manufacturer instructions. The quality of RNA was determined using the $\mathrm{A}_{260} /{ }_{280}$ absorbance ratio (1.6-1.8), and the integrity of the $18 \mathrm{~S}$ and $28 \mathrm{~S}$ ribosomal RNA bands was assessed on a $1 \%$ agarose gel. DNase treatment was conducted to remove genomic DNA from total RNA before reverse transcription. cDNA was synthesized using $1 \mu \mathrm{g}$ total RNA from each sample with a cDNA synthesis kit (TaKaRa, Japan).

\section{qRT-PCR assay for relative expression of IGFs}

Duck mRNA sequences of $\beta$-actin (EF667345), 18S rRNA (AF173614), IGF-I (DQ168593), IGF-II (JQ819263), IGF-IR (JX041184), and IGF-IIR (JX041185) were retrieved from GenBank. Primers were designed using Primer Premier 5.0 (Table 1) and synthesized by TaKaRa Biotechnology Co. Ltd (Dalian, China). PCR amplification was performed in a final volume of $10 \mu \mathrm{L}$ containing $5 \mu \mathrm{L}$ Master mix (TakaRa Biotechnology Co. Ltd.), $0.3 \mu \mathrm{L}$ $10 \mu \mathrm{M}$ of each primer, and $3.6 \mu \mathrm{L}$ double-distilled water. The amplification conditions were as follows: 1 cycle of 3 min at $94^{\circ} \mathrm{C} ; 35$ cycles of $30 \mathrm{~s}$ at $94^{\circ} \mathrm{C}, 40 \mathrm{~s}$ at the respective annealing temperature of each primer pair (see Table 1), and $45 \mathrm{~s}$ at $72^{\circ} \mathrm{C}$; and a final extension of $8 \mathrm{~min}$ at $72^{\circ} \mathrm{C}$. The authenticity of the amplified fragment was verified through sequencing.

\begin{tabular}{|c|c|c|c|}
\hline Primer name & Primer sequence (5'-3') & Annealing temperature $\left({ }^{\circ} \mathrm{C}\right)$ & Product length $(\mathrm{bp})$ \\
\hline IGF-I-F & ATCCAGCAGTAGACGCTTACACC & 61 & 117 \\
\hline IGF-I-R & CGTGCAGACTTAGGTGGCTTTA & & \\
\hline IGF-II-F & CAGTGGGACGAAATAACAGGA & 59 & 115 \\
\hline IGF-II-R & CGCTCAGACTTGACGGACTT & & \\
\hline IGF-IR-F & GGTATTCCACСТСАСТСТССТ & 60 & 160 \\
\hline IGF-IR-R & ААСТTССТТСАСААСТССАТСТ & & \\
\hline IGF-IIR-F & TGCTGCTTGCTTGATACACGA & 56 & 194 \\
\hline IGF-IIR-R & GTTCTCСТСТСТTTGATGGGCA & & \\
\hline$\beta$-actin-F & CAACGAGCGGTTCAGGTGT & 60 & 92 \\
\hline$\beta$-actin-R & TGGAGTTGAAGGTGGTCTCG & & \\
\hline 18S rRNA-F & TTGGTGGAGCGATTTGTC & 60 & 129 \\
\hline 18S rRNA-R & ATCTCGGGTGGCTGAACG & & \\
\hline
\end{tabular}


Expression levels of mRNAs were measured with qRT-PCR by using an IQ5 (Bio-Rad, USA) with 96 wells and a TaKaRa ExTaq ${ }^{\mathrm{TM}}$ RT-PCR Kit and SYBR Green dye (TaKaRa). The qRT-PCR was performed in a volume of $12.5 \mu \mathrm{L}$ containing $6.25 \mu \mathrm{L} \mathrm{SYBR}{ }^{\circledR}$ Premix Ex Taq ${ }^{\mathrm{TM}}$ II, $0.25 \mu \mathrm{L} 10 \mu \mathrm{M}$ of each primer, and $1 \mu \mathrm{L}$ cDNA. The cycling procedure consisted of an initial denaturation cycle for $10 \mathrm{~s}$ at $95^{\circ} \mathrm{C}$ and 40 cycles of $5 \mathrm{~s}$ at $95^{\circ} \mathrm{C}, 30 \mathrm{~s}$ at $60^{\circ} \mathrm{C}$, and a final extension at $68^{\circ} \mathrm{C}$ for $3 \mathrm{~min}$. To verify the absence of nonspecific amplification, we performed melting curve analysis after the completion of RT-PCR. The melting protocol consisted of heating from $55^{\circ}$ to $95^{\circ} \mathrm{C}$ at a rate of $0.5^{\circ} \mathrm{C}$ per step, and each step was held for $4 \mathrm{~s}$ for data acquisition. Standard curves were generated using a $10^{-3}-10^{-10}$ dilution series template of PCR product for the $\beta$-actin, 18S, IGF-I, IGF-II, IGF-IR, and IGF-IIR genes. The $2^{-\Delta \Delta C T}$ method of quantification (Livak and Schmittgen, 2001) was used to calculate the expression of the target genes relative to the housekeeping genes: $\beta$-actin (EF667345) and 18S rRNA (AF173614) (Li et al., 2010).

\section{Statistical analyses}

All data were analyzed using the SPSS statistical software (version 13.0, SPSS Inc., USA). To evaluate general gene expression at postnatal development weeks 1-8, we used the univariate procedure of the generalized linear model (with developmental age and strain as fixed factors and a target gene as the development variable), in which the Duncan multiple range test option was selected. Data of ontogenic changes of gene expression in 4 genes (IGFI, IGF-II, IGF-IR, and IGF-IIR) were subjected to one-way analysis of variance followed by the Duncan multiple range test to compare the means. Significance for differences was set at $\mathrm{P}$ $\leq 0.05$. The Pearson correlation coefficient was used to characterize the relationship between gene mRNA expression and muscle tissue (breast, leg) weight.

\section{RESULTS}

\section{Expression levels of IGF system genes in duck muscle tissues during the postnatal development stage}

IGF mRNA expression was detected in 3 muscle tissues (Figure 1). In breast muscle, IGF-I and IGF-II expression was the highest at week 1 , and then decreased quickly and stayed at a relatively lower level. IGF-IR and IGF-IIR expression was relatively low at week 1 and increased progressively. The leg muscle had the highest mRNA expression of the IGF-I and IGF-II genes at week 3. In myocardial tissue, the expression of the IGF-IR and IGF-IIR genes exhibited a "rise-decline" development trend.

\section{Expression patterns of IGF genes in various duck tissues}

The developmental mRNA expression patterns of the IGF system genes during the early postnatal development growth stage in ducks were analyzed. The expression patterns of IGF-I and IGF-IR and of IGF-II and IGF-IIR in breast muscle (Figure 2A), leg muscle (Figure 2B), and myocardial tissue (Figure 2C) were compared. 
A1

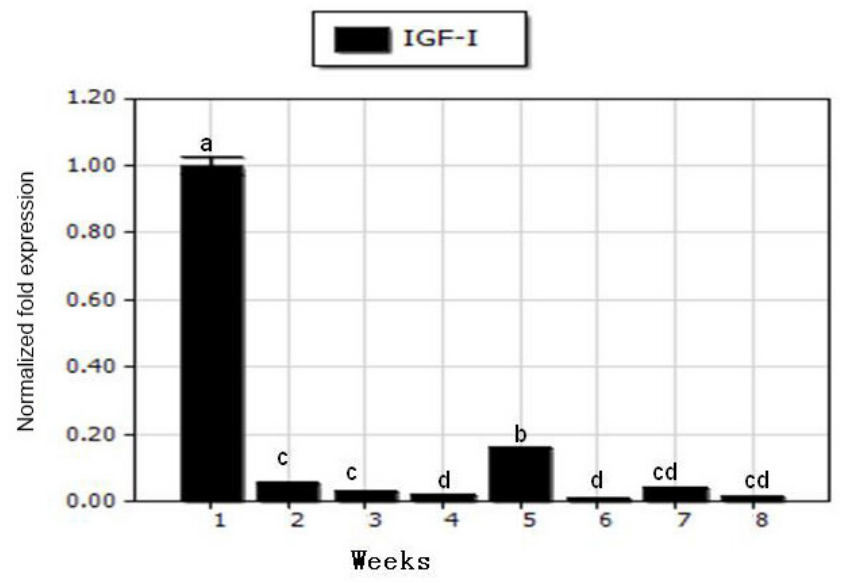

A2

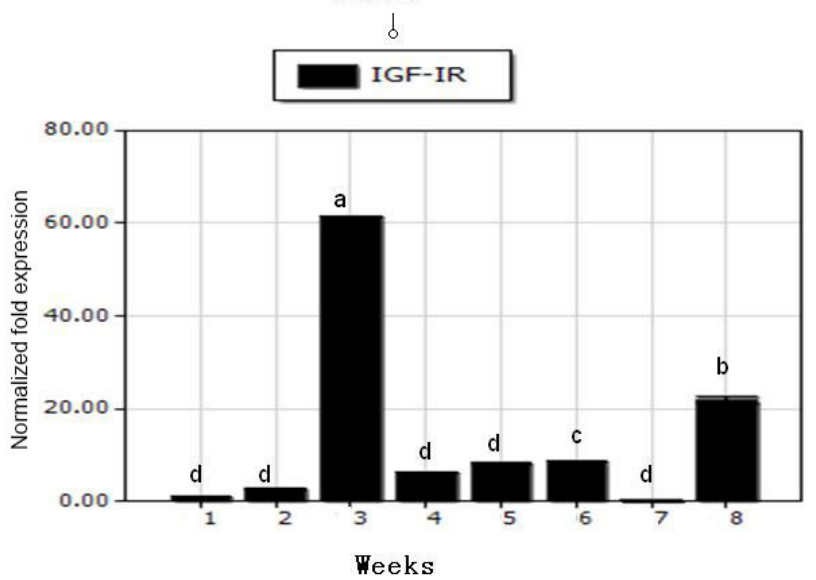

A3

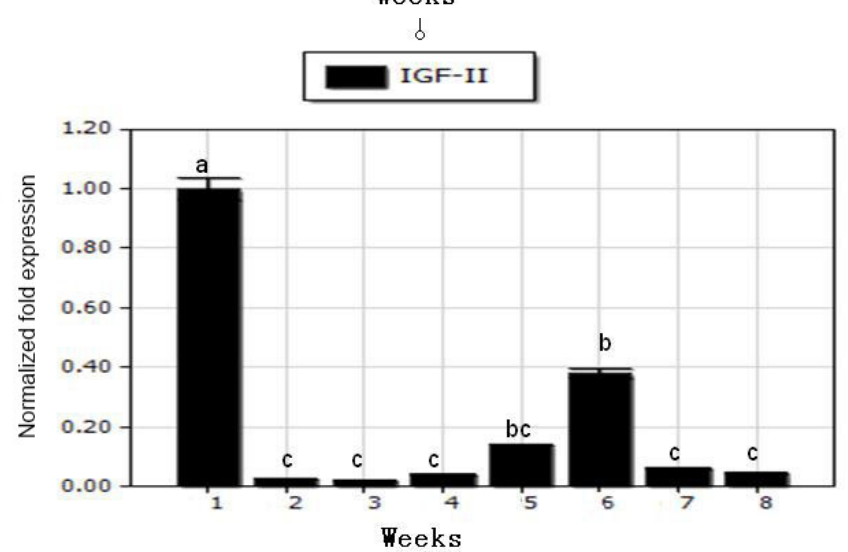

Figure 1. Expression of IGF system genes in different duck muscle tissues. A. Relative expression of IGF-I (A1), IGF-IR (A2), IGF-II (A3), and IGF-IIR (A4) in breast muscle. B. Relative expression of IGF-I (B1), IGF-IR (B2), IGF-II (B3), and IGF-IIR (B4) in leg muscle. C. Relative expression of IGF-I (C1), IGF-IR (C2), IGF-II (C3), and IGF-IIR (C4) in myocardial tissue, and we chose the first data of week 1 age in every tissue as control. Different letters are significant different $(\mathrm{P}<0.05)$.

Continued on next page 
Figure 1. Continued.

A4

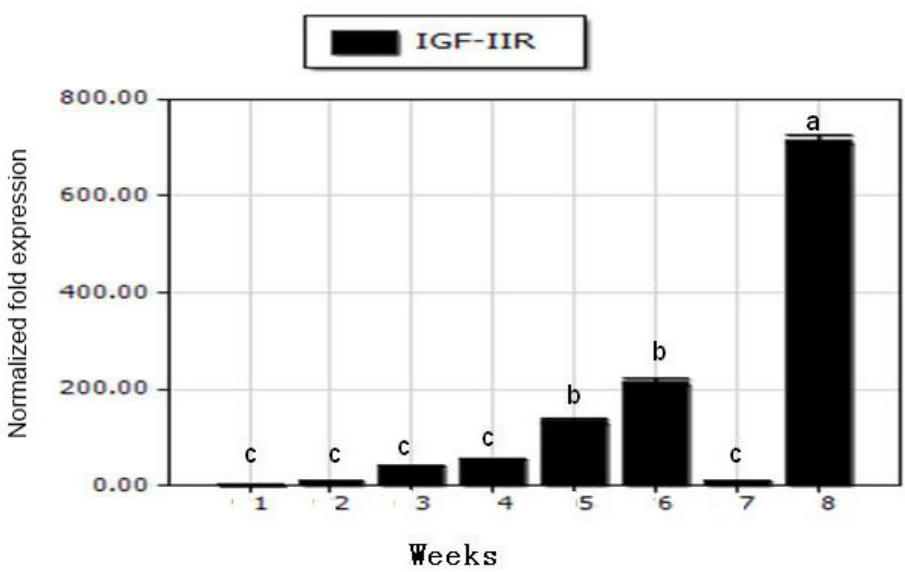

B1
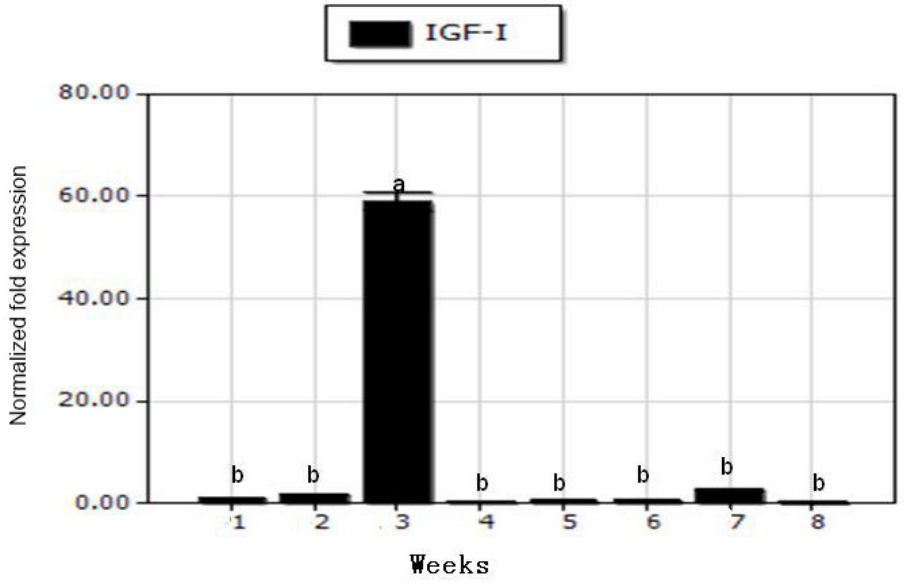

B2

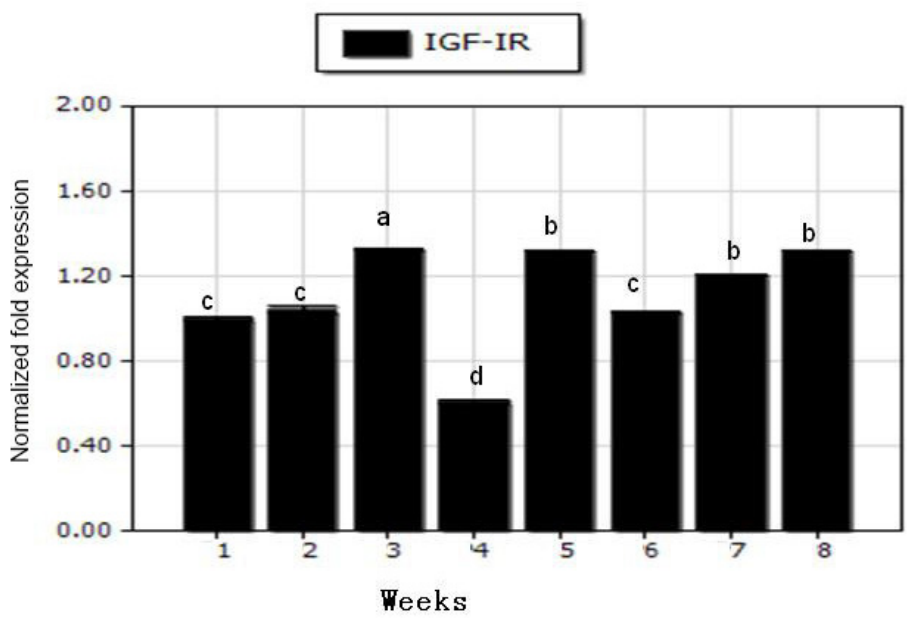

Continued on next page 
Figure 1. Continued.

B3

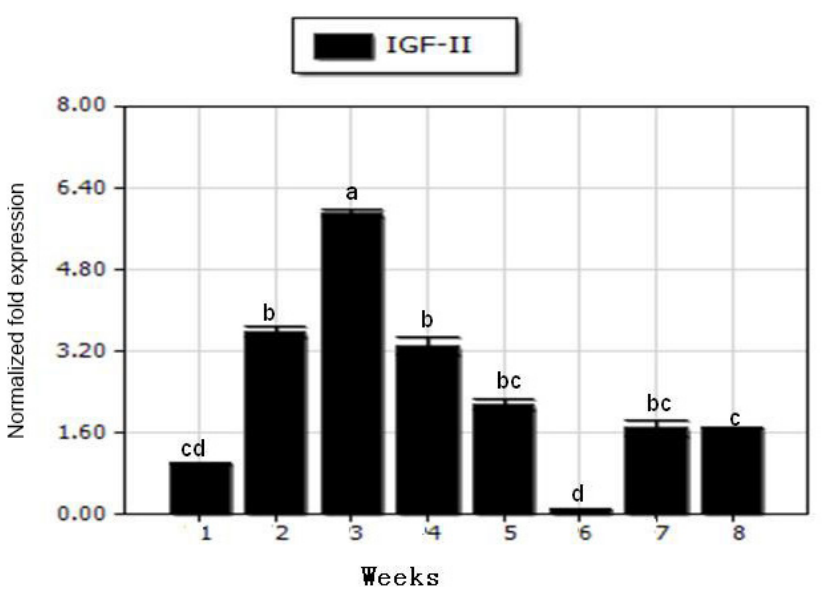

B4

$$
\text { IGF-IIR }
$$

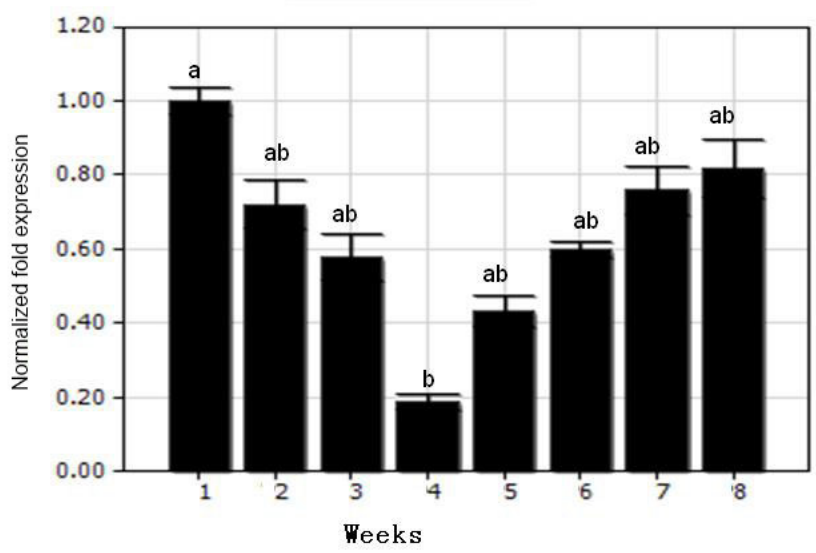

C1
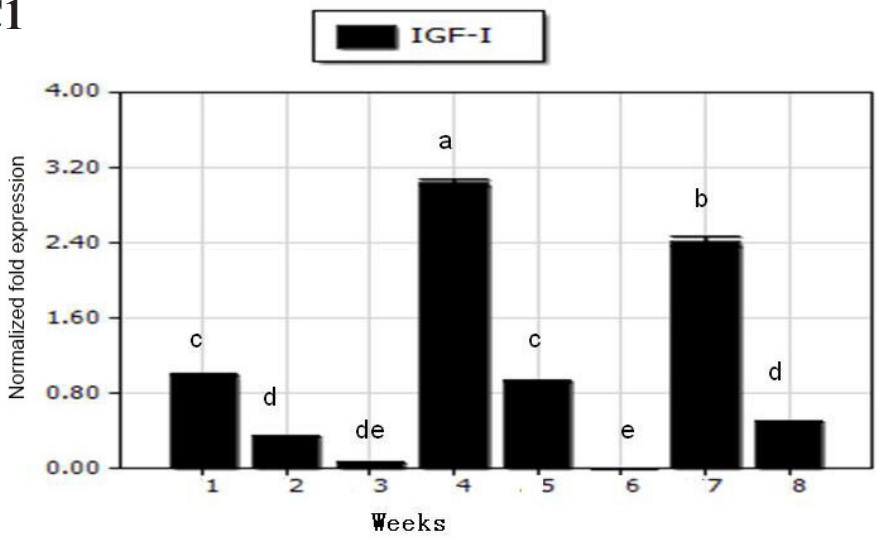

Continued on next page 
Figure 1. Continued.

\section{C2}

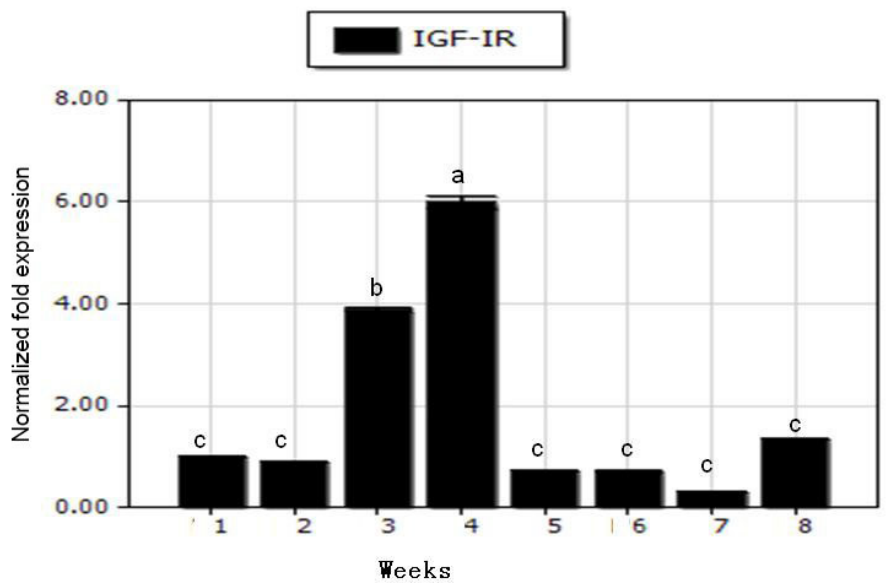

C3

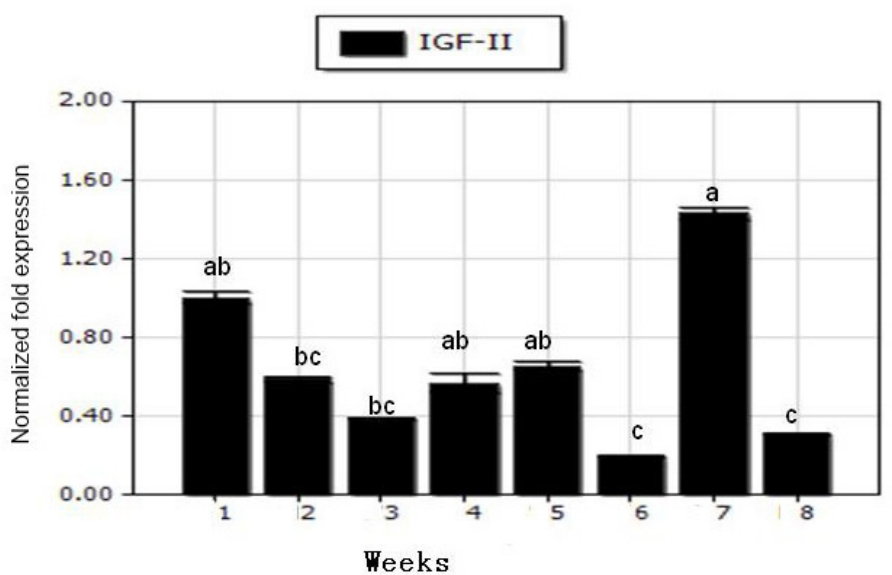

C4

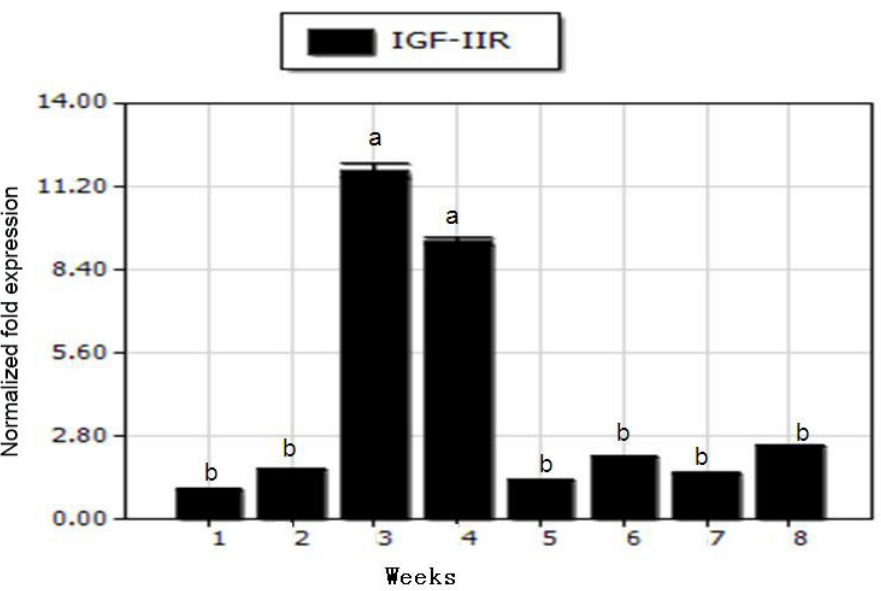


A

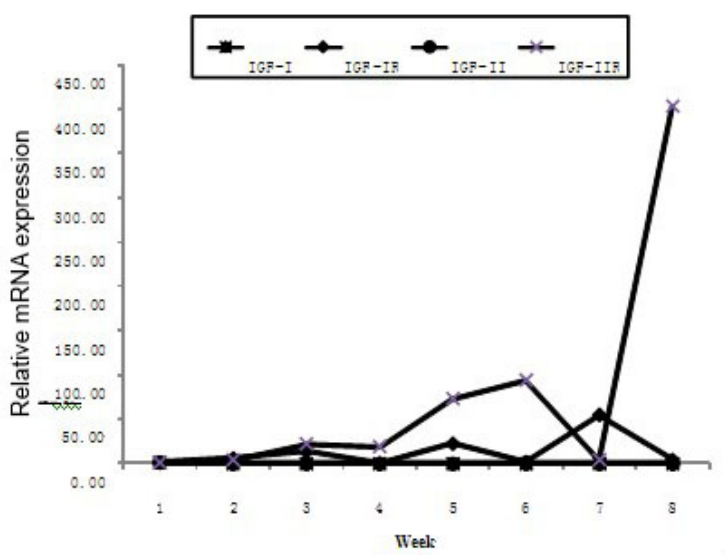

B

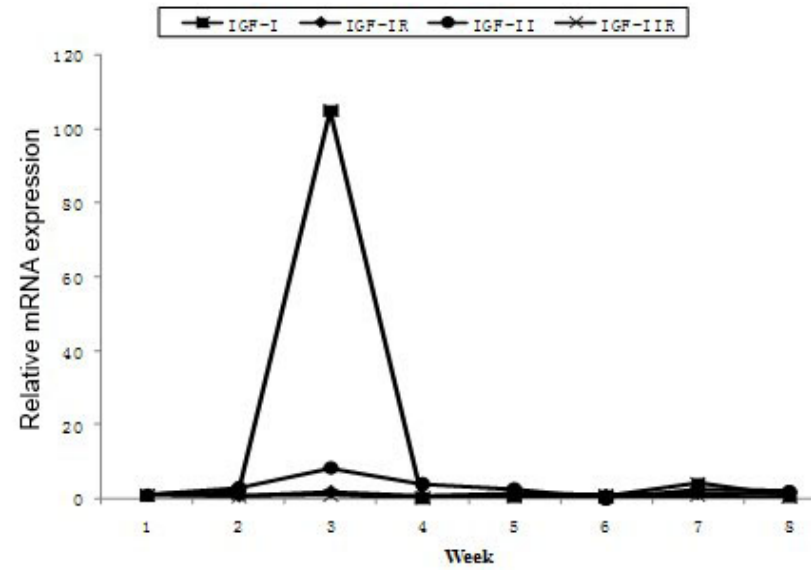

C
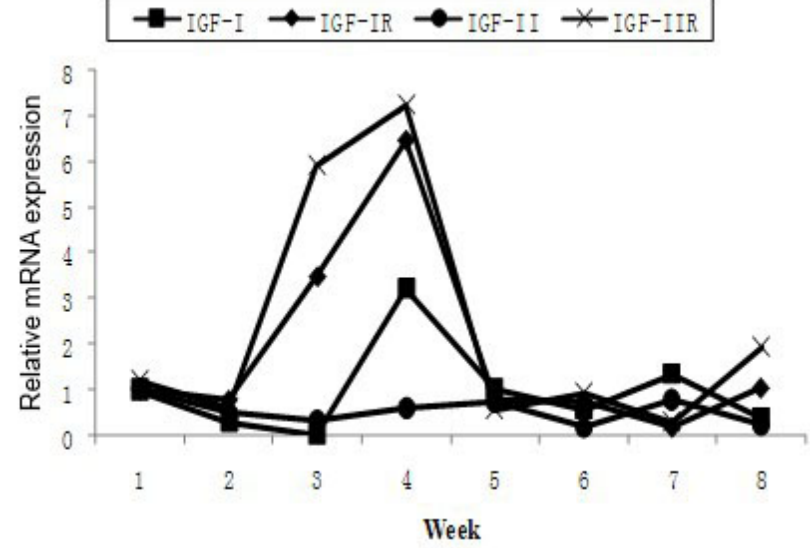

Figure 2. Expression of IGF genes in different tissues of duck. A. Expression pattern comparison between IGF-I, IGF-IR, IGF-II, and IGF-IIR in breast muscle. B. Expression pattern comparison between IGF-I, IGF-IR, IGF-II, and IGF-IIR in leg muscle. C. Expression pattern comparison between IGF-I, IGF-IR, IGF-II, and IGF-IIR in myocardial tissue. 
The expression patterns in these muscle tissues differed. As shown in Figure 2, the expression of IGF-IR was relatively higher than that of IGF-I in all of the tissues, except the leg muscle, and the expression of IGF-IIR was relatively higher than that of IGF-II in all 3 tissues.

In breast muscle, the expression of IGF-IR was relatively higher than that of IGF-IIR at week 3. After week 3, the mRNA expression level of IGF-IR declined quickly, whereas mRNA expression of IGF-IIR increased. During week 4, the expression of IGF-IIR was relatively higher than that of IGF-IR. The expression of IGF-IIR was the highest among these 4 genes after week 4. In leg muscle, the expression level of IGF-I was higher than that of IGFII before week 4, and the expression level of IGF-IR was also relatively higher than that of IGF-IIR. In myocardial tissue, the expression patterns of IGF-I and IGF-IR and IGF-II and IGF-IIR were roughly the same before week 4; however, they differed during weeks 4 and 6 . IGF-I and IGF-IR exhibited a similar expression pattern, which both increased and declined. However, the expression of IGF-II and IGF-IIR was different, exhibiting a pattern in which IGF-II expression increased when IGF-IIR expression declined and vice versa.

\section{Correlation coefficients between duck muscle tissue weight and mRNA expression of IGFs during the postnatal period of ducks}

The results showed that at week 4, IGF-II mRNA expression was negatively correlated with leg muscle weight $(\mathrm{P}<0.05)$. IGF-IIR expression was also negatively correlated with breast muscle weight $(\mathrm{P}<0.01)$. IGF-IR expression was positively correlated with breast muscle weight but negatively correlated with breast muscle weight at week 8 . IGF-IR expression was positively correlated with leg muscle weight at week 6 . Table 2 shows the correlation coefficients between duck muscle tissue weight and mRNA expression of IGFs from week 4 to week 8 in ducks.

\begin{tabular}{|c|c|c|c|c|c|c|}
\hline \multirow[t]{3}{*}{ Gene } & \multicolumn{6}{|c|}{ Pearson's correlation } \\
\hline & \multicolumn{3}{|c|}{ BMW } & \multicolumn{3}{|c|}{ LMW } \\
\hline & 4 weeks & 6 weeks & 8 weeks & 4 weeks & 6 weeks & 8 weeks \\
\hline IGF-I & 0.182 & -0.625 & 0.228 & -0.911 & -0.026 & -0.613 \\
\hline IGF-IR & 0.679 & 0.026 & -0.917 & -0.044 & 0.761 & -0.952 \\
\hline IGF-II & -0.937 & -0.955 & -0.926 & $-1.000 *$ & -0.971 & -0.835 \\
\hline IGF-IIR & $-1.000^{* * *}$ & -0.699 & 0.925 & -0.947 & -0.789 & -0.892 \\
\hline
\end{tabular}

$* \mathrm{P}<0.05, * * \mathrm{P}<0.01$.

\section{DISCUSSION}

\section{A specific, separate expression pattern exists for IGF system genes in duck leg muscle, breast muscle, and myocardial tissues}

IGFs play a critical role in myogenesis as well as in the regeneration and hypertrophy of muscles in adult vertebrates. Myogenesis is a highly ordered process. During embryonic development, the muscle precursor cells commit to myogenic linage. After a period of prolif- 
eration, the myoblasts withdraw from the cell cycle, express muscle-specific genes, and eventually fuse with each other to form multinucleated myotubes (Buckingham et al., 2003; Duan et al., 2010). The expression of IGF-I system genes during skeletal muscle formation and hyperplasia is well understood, but few reports have described their expression in the postnatal early development growth stage. Yet this stage is critical for muscle tissue hypertrophy. In this study, we examined the expression patterns of IGF system genes during the postnatal early developmental growth stage in ducks. Breast muscle displayed the highest expression of IGF-I mRNA at week 1. It then declined, consistent with the observations of other researchers; for example, Yun et al. (2005) reported a dramatic decline in IGF-I expression in the breast muscles of Korean native Ogol chickens. These results suggest that the endocrine actions of IGF-I are more important than auto/paracrine actions in early postnatal growth in ducks.

IGF-II regulates cellular proliferation and differentiation through the endocrine and auto/paracrine systems. Previous studies by Radecki et al. (1997) have shown that the mRNA and protein expression of IGF-II declines and exists at low levels during postnatal growth in chickens. In our study, the duck breast muscle had the highest IGF-II mRNA at week 1 and then declined to a relatively lower level. Lu et al. (2009) have also reported that IGF-II mRNA expression decreased progressively from postnatal day 0 to postnatal day 42 in chickens, which is consistent with the results of other reports (Spencer et al., 1995, 1996; Richards et al., 2005). All of these findings suggest that IGF-II does not regulate growth after the postnatal period in birds.

IGF-IR expression in breast muscle is strong during the early postnatal period in chickens and then decreases (Yun et al., 2005). Our results showed that breast muscle displayed the highest expression the IGF-IR mRNA at week 3. Then, the expression of IGF-IR mRNA declined. Duclos et al. (1991) have reported that the highest expression of IGF-IR in chickens occurs at week 3 .

IGF-IIR/M6PR is ubiquitously expressed in cells and tissues in chickens (Hawkes and Kar, 2004). We found that in myocardial tissue, IGF-IIR mRNA expression was the highest at week 4, but in breast muscle, IGF-IIR mRNA expression was the highest at week 8 . These findings suggested that IGF-IIR mRNA expression was both tissue specific and developmentally regulated.

\section{Expression patterns of IGF-I/IGF-IR and IGF-II/IGF-IIR differ}

To characterize the expression of IGF genes further, we analyzed the expression pattern of IGF-I/IGF-IR and IGF-II/IGF-IIR in the 3 muscle tissues. The expression of IGF-IR was relatively higher than that of IGF-I in all of these tissues except leg muscle, and the expression of IGF-IIR was relatively higher than that of IGF-II in all tissues examined. In birds, IGF-I and IGF-II act as endocrine or paracrine/autocrine signals with physiological effects that are mainly mediated by their binding to a common receptor (IGF-IR) (McMurtry and Brocht, 1997). Researchers have reported that physiological conditions such as fasting (during which circulating IGF-I levels decline) result in unregulated expression of IGF-IR in rats (Liu and LeRoith, 1999; Bondy and Cheng, 2004). Evock-Clover et al. (2002) have found an inverse relationship between IGF-I and IGF-IR expression in skeletal muscle in response to a 48-h fast during the postnatal period in turkeys and 3-week-old broiler chickens (Evock-Clover et al., 2002). Matsumura et al. (1996) have reported that a 5-day fast of 4-week-old chickens increased liver IGF-IR mRNA approximately 2 -fold but that brain levels failed to change 
(Duclos, 2005). We determined that IGF-IR expression upregulated IGF-I expression in breast muscle, leg muscle, and myocardial tissue, suggesting that IGF-IR can upregulate IGF-I expression in muscle tissues.

IGF-IIR is structurally and functionally distinct from IGF-IR. IGF-IIR also acts as an M6PR. Although the biological actions of IGF-II are mainly mediated through IGF-IR, IGF-II/ M6PR participates in not only the clearance of extracellular IGF-II but also intracellular lysosomal enzyme transport. The synthesis of IGF-II is relatively growth hormone independent. Its expression is much higher during fetal development than during postnatal periods. IGF-II/ M6PR is ubiquitously expressed in cells and tissues, but some studies have demonstrated that its expression is both tissue specific and developmentally regulated (Hawkes and Kar, 2004; Velayudhan et al., 2007; Vardatsikos et al., 2009). We observed that during the early growth period, IGF-IIR expression upregulated IGF-II in breast and leg muscle, but in myocardial tissue, the expression pattern of IGF-II and IGF-IIR was different, exhibiting increased IGF-II expression when IGF-IIR expression declined and vice versa. Thus, the specific factors that influence the expression of IGF-I/IGF-IR and IGF-II/IGF-IIR in various duck tissues remain unclear, and more research is required to understand the regulation of these genes in avian species.

\section{A correlation exists between muscle tissue weight and IGF gene expression}

At present, several studies have reported positive or negative correlations between circulating IGF-I concentration and body growth in chickens (Hwa et al., 1998; Beccavin et al., 2001; Lu et al., 2009). Conlon and Kita (2002) have suggested that IGF-I infusion would increase muscle protein degradation as well as protein synthesis in fasted chicks. Lu et al. (2009, 2010) reported that IGF-I (P0-P42) is negatively correlated with breast muscle weight (BMW). Our results revealed that IGF-I mRNA expression was negatively correlated with BMW at week 6. Negative correlations were also found between IGF-I mRNA expression and leg muscle weight (LMW). However, at weeks 4 and 8, a positive correlation was found between IGF-I mRNA expression and BMW. These conflicting results have suggested that the association of IGF-I with the body growth of chickens depends on strain, nutrition, age, and sex.

Yun et al. (2005) have reported that the concentration of breast muscle IGF-II is negatively correlated with body growth at weeks 3 and 7, in contrast to the results of previous studies (Spencer et al., 1996; Yun et al., 2005; Llewellyn et al., 2007). Our results showed that IGF-II mRNA levels were negatively correlated with BMW and LMW, and especially that IGF-II mRNA levels were negatively correlated with LMW at week $4(\mathrm{P}<0.05)$. All these studies have shown that IGF-II has no effect on growth rate. In growing cattle, a positive correlation has been reported between the accretion rate of the longissimus muscle and the number of type I IGF receptors $(r=0.52)$ (Vestergaard et al., 2003). In chicken, there was a negative correlation between IGF-IR (P0-P42) and BMW (Lu et al., 2009). Our results showed that IGF-IR mRNA levels were positively correlated with BMW at week 4, negatively correlated with BMW at week 8, and positively correlated with LMW at week 6 . This study is the first to investigate the correlation between IGF-IIR and BMW and LMW in birds. Our results showed that IGF-IIR mRNA levels were negatively correlated with BMW and LMW from weeks 4 to 8 .

We investigated the expression of IGF system genes in duck muscle tissues during the early development growth stage. We discovered that mRNA expression of the 4 IGF genes has 
tissue-specific characteristics and are developmentally regulated. These findings suggested that the potential roles for these genes in regulating muscle hypertrophy and development differ in ducks. These results may guide the direction of future molecular regulation mechanism studies of IGF gene expression in ducks.

\section{ACKNOWLEDGMENTS}

Research supported by the Alternate Innovation Team of Science and Technology of Sichuan Province (\#2011JTD0032) and the "863" Program.

\section{REFERENCES}

Allan GJ, Flint DJ and Patel K (2001). Insulin-like growth factor axis during embryonic development. Reproduction 122: 31-39.

Beccavin C, Chevalier B, Cogburn LA, Simon J, et al. (2001). Insulin-like growth factors and body growth in chickens divergently selected for high or low growth rate. J. Endocrinol. 168: 297-306.

Bondy CA and Cheng CM (2004). Signaling by insulin-like growth factor 1 in brain. Eur. J. Pharmacol. 490: 25-31.

Brown J, Jones EY and Forbes BE (2009). Interactions of IGF-II with the IGF2R/cation-independent mannose-6-phosphate receptor mechanism and biological outcomes. Vitam. Horm. 80: 699-719.

Buckingham M, Bajard L, Chang T, Daubas P, et al. (2003). The formation of skeletal muscle: from somite to limb. $J$. Anat. 202: 59-68.

Castigliego L, Armani A, Grifoni G, Rosati R, et al. (2010). Effects of growth hormone treatment on the expression of somatotropic axis genes in the skeletal muscle of lactating Holstein cows. Domest. Anim. Endocrinol. 39: 40-53.

Conlon MA and Kita K (2002). Muscle protein synthesis rate is altered in response to a single injection of insulin-like growth factor-I in seven-day-old Leghorn chicks. Poult. Sci. 81: 1543-1547.

Duan C, Ren H and Gao S (2010). Insulin-like growth factors (IGFs), IGF receptors, and IGF-binding proteins: roles in skeletal muscle growth and differentiation. Gen. Comp. Endocrinol. 167: 344-351.

Duclos MJ (2005). Insulin-like growth factor-I (IGF-1) mRNA levels and chicken muscle growth. J. Physiol. Pharmacol. 56 (Suppl 3): 25-35.

Duclos MJ, Wilkie RS and Goddard C (1991). Stimulation of DNA synthesis in chicken muscle satellite cells by insulin and insulin-like growth factors: evidence for exclusive mediation by a type-I insulin-like growth factor receptor. $J$. Endocrinol. 128: 35-42.

Duclos MJ, Beccavin C and Simon J (1999). Genetic models for the study of insulin-like growth factors (IGF) and muscle development in birds compared to mammals. Domest. Anim. Endocrinol. 17: 231-243.

Dupont J and Holzenberger M (2003). Biology of insulin-like growth factors in development. Birth Defects Res. C Embryo Today 69: 257-271.

Evock-Clover CM, Poch SM, Richards MP, Ashwell CM, et al. (2002). Expression of an uncoupling protein gene homolog in chickens. Comp. Biochem. Physiol. A Mol. Integr. Physiol. 133: 345-358.

Florini JR, Ewton DZ and Roof SL (1991). Insulin-like growth factor-I stimulates terminal myogenic differentiation by induction of myogenin gene expression. Mol. Endocrinol. 5: 718-724.

Frost RA and Lang CH (2003). Regulation of insulin-like growth factor-I in skeletal muscle and muscle cells. Minerva Endocrinol. 28: 53-73.

Harris LK and Westwood M (2012). Biology and significance of signalling pathways activated by IGF-II. Growth Factors 30: 1-12.

Hawkes C and Kar S (2004). The insulin-like growth factor-II/mannose-6-phosphate receptor: structure, distribution and function in the central nervous system. Brain Res. Brain Res. Rev. 44: 117-140.

Heinemeier KM, Mackey AL, Doessing S, Hansen M, et al. (2012). GH/IGF-I axis and matrix adaptation of the musculotendinous tissue to exercise in humans. Scand. J. Med. Sci. Sports 22: e1-e7.

Holzenberger M and Lapointe F (2000). Expression of insulin-like growth factor-I (IGF-I) and IGF-II in the avian brain: relationship of in situ hybridization patterns with IGF type 1 receptor expression. Int. J. Dev. Neurosci. 18: 69-82.

Holzenberger M, Lapointe F and Ayer-LeLievre C (2000). Expression of insulin-like growth factor-I (IGF-I) and IGFII in the avian brain: relationship of in situ hybridization patterns with IGF type 1 receptor expression. Int. J. Dev. Neurosci. 18: 69-82. 
Huybrechts LM, King DB, Lauterio TJ, Marsh J, et al. (1985). Plasma concentrations of somatomedin-C in hypophysectomized, dwarf and intact growing domestic fowl as determined by heterologous radioimmunoassay. $J$. Endocrinol. 104: 233-239.

Hwa V, Tomasini-Sprenger C, Bermejo AL, Rosenfeld RG, et al. (1998). Characterization of insulin-like growth factorbinding protein-related protein-1 in prostate cells. J. Clin. Endocrinol. Metab. 83: 4355-4362.

Jones JI and Clemmons DR (1995). Insulin-like growth factors and their binding proteins: biological actions. Endocr. Rev. 16: 3-34.

Li L, Liu HH, Xu F, Si JM, et al. (2010). MyoD expression profile and developmental differences of leg and breast muscle in Peking duck (Anas platyrhynchos domestica) during embryonic to neonatal stages. Micron 41: 847-852.

Liu JL and LeRoith D (1999). Insulin-like growth factor I is essential for postnatal growth in response to growth hormone. Endocrinology 140: 5178-5184.

Livak KJ and Schmittgen TD (2001). Analysis of relative gene expression data using real-time quantitative PCR and the $2^{-\Delta \Delta \mathrm{CT}}$ method. Methods 25: 402-408.

Llewellyn S, Fitzpatrick R, Kenny DA, Murphy JJ, et al. (2007). Effect of negative energy balance on the insulin-like growth factor system in pre-recruitment ovarian follicles of post partum dairy cows. Reproduction 133: 627-639.

Lu FZ, Chen J, Wang XX and Liu HL (2009). Investigation of the Insulin-like growth factor system in breast muscle during embryonic and postnatal development in langshan and arbor acres chickens subjected to different feeding regimens. Asian-Aust. J. Anim. Sci. 22: 471-482.

Lu FZ, Jiang ZY, Wang XX, Luo YH, et al. (2010). Role of the insulin-like growth factor system in epiphyseal cartilage on the development of Langshan and Arbor Acres chickens, Gallus domesticus. Poult. Sci. 89: 956-965.

Lunetta C, Serafini M, Prelle A, Magni P, et al. (2012). Impaired expression of insulin-like growth factor-1 system in skeletal muscle of amyotrophic lateral sclerosis patients. Muscle Nerve 45: 200-208.

Matsumura Y, Domeki M, Sugahara K, Kubo T, et al. (1996). Nutritional regulation of insulin-like growth factor-I receptor mRNA levels in growing chickens. Biosci. Biotechnol. Biochem. 60: 979-982.

McMurtry JP (1998). Nutritional and developmental roles of insulin-like growth factors in poultry. J. Nutr. 128: 302S-305S.

McMurtry JP and Brocht DM (1997). Developmental changes in embryonic and extra-embryonic insulin-like growth factor-I tissue concentrations in the turkey embryo. Poult. Sci. 76: 894-900.

Pym RA, Johnson RJ, Etse DB and Eason P (1991). Inheritance of plasma insulin-like growth factor-I and growth rate, food intake, food efficiency and abdominal fatness in chickens. Br. Poult. Sci. 32: 285-293.

Radecki SV, Capdevielle MC, Buonomo FC and Scanes CG (1997). Ontogeny of insulin-like growth factors (IGF-I and IGF-II) and IGF-binding proteins in the chicken following hatching. Gen. Comp. Endocrinol. 107: 109-117.

Richards MP, Poch SM and McMurtry JP (2005). Expression of insulin-like growth factor system genes in liver and brain tissue during embryonic and post-hatch development of the turkey. Comp. Biochem. Physiol. A Mol. Integr. Physiol. 141: 76-86.

Scanes CG, Dunnington EA, Buonomo FC, Donoghue DJ, et al. (1989). Plasma concentrations of insulin like growth factors (IGF-)I and IGF-II in dwarf and normal chickens of high and low weight selected lines. Growth Dev. Aging 53: 151-157.

Simmen FA, Badinga L, Green ML, Kwak I, et al. (1998). The porcine insulin-like growth factor system: at the interface of nutrition, growth and reproduction. J. Nutr. 128: 315S-320S.

Spencer GS, Decuypere E, Buyse J, Hodgkinson SC, et al. (1995). Passive immunization of insulin-like growth factor (IGF)-1 and of IGF-1 and IGF-2 in chickens. Comp. Biochem. Physiol. C Pharmacol. Toxicol. Endocrinol. 110: 29-33.

Spencer GS, Decuypere E, Buyse J and Zeman M (1996). Effect of recombinant human insulin-like growth factor-II on weight gain and body composition of broiler chickens. Poult. Sci. 75: 388-392.

Tiffin N, Adi S, Stokoe D, Wu NY, et al. (2004). Akt phosphorylation is not sufficient for insulin-like growth factorstimulated myogenin expression but must be accompanied by down-regulation of mitogen-activated protein kinase/ extracellular signal-regulated kinase phosphorylation. Endocrinology 145: 4991-4996.

Vardatsikos G, Sahu A and Srivastava AK (2009). The insulin-like growth factor family: molecular mechanisms, redox regulation, and clinical implications. Antioxid. Redox Signal. 11: 1165-1190.

Velayudhan BT, Govoni KE, Hoagland TA and Zinn SA (2007). Growth rate and changes of the somatotropic axis in beef cattle administered exogenous bovine somatotropin beginning at two hundred, two hundred fifty, and three hundred days of age. J. Anim. Sci. 85: 2866-2872.

Vestergaard M, Purup S, Frystyk J, Lovendahl P, et al. (2003). Effects of growth hormone and feeding level on endocrine measurements, hormone receptors, muscle growth and performance of prepubertal heifers. J. Anim. Sci. 81: 21892198.

Wu G, Siegel PB, Gilbert ER, Yang N, et al. (2011). Expression profiles of somatotropic axis genes in lines of chickens 
divergently selected for 56-day body weight. Anim. Biotechnol. 22: 100-110.

Xu D, Liang G, Yan YE, He WW, et al. (2012). Nicotine-induced over-exposure to maternal glucocorticoid and activated glucocorticoid metabolism causes hypothalamic-pituitary-adrenal axis-associated neuroendocrine metabolic alterations in fetal rats. Toxicol. Lett. 209: 282-290.

Yun JS, Seo DS, Kim WK and Ko Y (2005). Expression and relationship of the insulin-like growth factor system with posthatch growth in the Korean Native Ogol chicken. Poult. Sci. 84: 83-90. 